\title{
Creative and Innovative Products During the Pandemic
}

\author{
I Ketut Sida Arsa ${ }^{1,{ }^{*}}$ Ni Luh Putu Agustini Karta ${ }^{2}$ Ni Made Ary Widiastini ${ }^{3}$ Made
}

Aristia Prayudi ${ }^{4}$

\author{
${ }^{1}$ Department of Art Cradt, Institut Seni Indonesia, Denpasar, Indonesia \\ ${ }^{2}$ Department of Management Hospitality Tourism, Universitas Triatma Mulya, Denpasar, Indonesia \\ ${ }^{3}$ Department of Management, Universitas Pendidikan Ganesha, Singaraja, Indonesia \\ ${ }^{4}$ Department of Management, Universitas Pendidikan Ganesha, Singaraja, Indonesia \\ *Corresponding author. Email: rugos28kt@gmail.com
}

\begin{abstract}
The Covid-19 pandemic has had a negative impact on almost all aspects of the Indonesian economy, including Bali. Bali, which is very famous for its creative products, especially its handicrafts, is also experiencing problems with the entry of a virus outbreak that has led to the implementation of various forms of social restrictions. Nevertheless, business actors, whether small, medium or large, are still a system that must try to immediately find a solution to defend their business from bankruptcy. Under these conditions, every business actor is required to be able to think creatively and innovatively, with the aim of being able to survive the COVID-19 pandemic. To be able to produce products that are accepted by the market during the pandemic, business actors must look at the lifestyle in the community. However, in any situation, human choice remains in two choices, namely creative and pragmatic, which of course are expected to be able to have good dialectics, so that creative and innovative products produced by business actors are consumed by the people who become their market. Based on searches on the internet and various social media, there are four products that are quite widely accepted by the market, including ready-to-serve coffee, packaged chili sauce, hand sanitizer, and masks.
\end{abstract}

Keywords: Product, Creative, Innovative, Pandemic, Covid-19.

\section{INTRODUCTION}

The Covid-19 pandemic in practice does not necessarily make people give up, especially those who have businesses and must be maintained in order to keep getting income, and maintain the welfare of their employees. As Talcott Parson's idea is that a system must be able to maintain itself as much as possible in a balanced state, then it must have the means to mobilize resources to achieve its goals [1]. In this case, business actors must be able to utilize their human resources as optimally as possible in order to produce creative and innovative products to be consumed by the market during the pandemic. One of the things that business actors pay attention to in developing their products is understanding people's lifestyles, which will continue to develop even during the pandemic. Reference [2], lifestyle as a pattern that a person does by using the money and time he has, so that it can be a basis for consideration to understand how consumers think and choose a product.

During the COVID-19 pandemic, social restrictions were imposed in various regions with various scales, adjusting to the conditions for the spread of the Covid-19 virus that occurred in the area concerned. This, in its implementation, has a negative impact on the continuity of the existing business. Social restrictions which are restrictions on human activities [3], especially large-scale ones as a result of the pandemic, have caused economic losses nationally. As stated by Mrs. Sri Mulyani, (The Minister of Finance, in the central development coordination meeting, said The economic value lost due to Covid-19 is estimated at IDR 1,356 trillion [4]. In this case, closing offices, limited opening times for shops, stalls and markets, will certainly have an impact on the economic cycle.

Producers are unable to sell their products, consumers are limited in their consumption space, making products difficult to reach the target consumers. Coupled with the number of people who lost their jobs, causing the products produced by producers cannot be bought, because they do not have money. In this context, consumers are required to be more effective and efficient in choosing products, namely they continue to consume, but of course only products that are really needed, [5], primary needs.

In the conditions of the covid-19 pandemic, almost every individual is trying to make savings, considering 
that it is not yet known how long the virus will spread and government policies in dealing with it are implemented. In this condition, every business actor must also be able to produce creative and innovative products, understand consumer conditions, and take opportunities for every need that occurs, both in the context of fulfilling human daily life and at certain times aimed at maintaining his lifestyle. The situation of the covid-19 pandemic that is present in the modern era, where humans have chosen their lifestyle, in its implementation does not necessarily stop their desire to show their existence. In this case, consumption as emphasized by Bourdieu [6] which includes signs, symbols, ideas, and values, used as a way to separate one social group from another, is very difficult to stop directly, including during a pandemic, where Some people's income has decreased.

This paper examines consumer needs for certain products, which have an impact on the presence of business opportunities regarding these products, in order to meet consumer needs, not only primary needs, but also their needs to actualize themselves in society. The business opportunities that are present or persist during the pandemic are interesting to observe, with the hope that consumers' choices and consumption methods will be known which will lead to the emergence of new product ideas that are more creative and innovative, so that economic problems can be resolved, even though they are within the scope of local. This paper provides information about business opportunities that can be occupied by startups that are currently developing a lot.

\section{LITERATURE REVIEW}

Humans as homo economicus, then he must work to be able to meet the needs of his life. Likewise, human nature is homo faber, namely a working creature, so work is a human identity in the sense that without work humans cannot become fully human, where by working there is a goal to be achieved [7]. One of the goals of human work is to earn money to meet their own needs as individual beings and their families. If it is associated with the creative industry, the nature of humans as economic creatures causes humans to always be able to see various opportunities that can become economic resources. The variety of products needed by the community at large has implications for the emergence of creative ideas to produce goods that are in accordance with market tastes.

Creative economy in its application always relies on the development of science and technology, as the view of [8] explains that science and technology are the main inputs in encouraging economic development in order to create good economic growth. Reference [9] explicitly states that the development of Indonesia's creative economy until 2025 is a form of optimism and overflow of aspirations to support realizing Indonesia's vision of becoming a developed country. For him, the creative economy which includes the creative industry is believed to be able to contribute significantly to the nation's economy. Likewise, along with the rapid development of information technology and lifestyle, this can make the creative economy in Indonesia grow and develop well through various creative and innovative product developments. In this case, technology can support the process of developing creative and innovative products, both in the production, distribution and marketing processes.

The importance of the role of information technology in the development of creative industries is in line with the ideas of [10] that technology is very helpful in the distribution and marketing process of products, this also occurs in the creative industry in Indonesia. Sales of products that are not only local, but also national and international require producers to have and master the information technology they need. Even, when in the era of the COVID-19 pandemic there was a market shift from offline to online, business owners must be able to take advantage of available information technology. The creative economy that was born after the information economy has helped the creative industries that process it in the production, distribution and marketing processes.

\section{METHOD}

This research on creative and innovative products was conducted by conducting surveys on social media and direct observations in several place, such as WhatsApp, Instagram, and Face Book. This paper uses an ethnographic approach as a variant of the qualitative approach, [11] with the aim of obtaining an in-depth description and analysis of culture based on intensive field research. Through this approach, creative and innovative products during the COVID-19 pandemic that were found on the internet and in the field, were analyzed using a textual approach using the concept of difference in Derrida's concept [12], which was applied to any discussion of problems accompanied by the use of theory eclectic.

\section{RESULTS \& DISCUSSION}

Humans as thinking creatures, make humans never stop thinking about something, including in this condition during the COVID-19 pandemic situation,

humans are limited in their space of movement and have an impact on their social and economic life. Some of them stop working for various reasons. However, humans as social beings are essentially required to work in order to fulfill their life needs [7], where humans are working creatures (homo faber). Likewise, reference [13] using a post phenomenological perspective and material engagement theory, homo faber can be understood as a creative way carried out by humans, including in order to maintain their lives, by working, earning a certain amount of money, which is used to meet the needs of life both primary, secondary and tertiary. 


\subsection{Ready-to-drink Coffee of Various Brands Available With Various Flavors.}

Drinking coffee in its development has become a consumptive behavior, namely a person drinking a cup of coffee not only aims to fulfill his primary needs, namely eliminating thirst and eliminating sleepiness, but already exists at the level of fulfilling tertiary needs as a form of showing his existence. Drinking a cup of coffee [14], is not just a guide to taste, but has become part of people's lifestyles. In practice, people will choose coffee shops that provide different types of services to consumers, with the hope that coffee business actors, namely coffee shop owners, can lead the target consumer community to have coffee in their place.

Eligo ergo sum, the classical philosophy of self in neoclassical economics [15], as a transcendental trait in humans that convinces them to choose something to show their circumstances. Eligo ergo sum (because I choose me, I choose therefore I am, I am stylish therefore I am). Reference [16] asserts that a person will be seen and seen if he shows a style, including the lifestyle he chooses, so that he is able to show his identity in a class or social space, which is able to give him a sense of satisfaction and fulfill his tertiary needs.

Lifestyle in the form of how people enjoy coffee in a coffee shop with a certain identity, provides opportunities for coffee business actors to take opportunities for people's lifestyles [17]. Lifestyle [18], the way humans give meaning to themselves and their lives, then they will need a medium and space in order to express the meaning that is hidden in their actions, namely the space of language and objects in which an image has a very important and central role. In this case, image [18], is a category in the symbolic relationship that exists between humans and the world of objects, where humans need to actualize themselves into various worlds of reality, including drinking at a famous coffee shop like Starbucks. Meanwhile, for those who are in the lower middle class, choose a representative coffee shop to help them show their identity, and of course at an affordable price. In this context, drinking coffee at home is different from drinking coffee in a coffee shop that offers a variety of services.

Understanding the development of the way people consume coffee, namely choosing a coffee shop according to their class and economic ability, provides good opportunities for those who have a business spirit. As can be seen in various regions in Bali, for example, we can find many coffee shops, both franchises and those built with their own capital, ideas, designs, and concoctions, relying on their personal experiences, both as coffee connoisseurs and former coffee shoppers. work in a coffee shop.

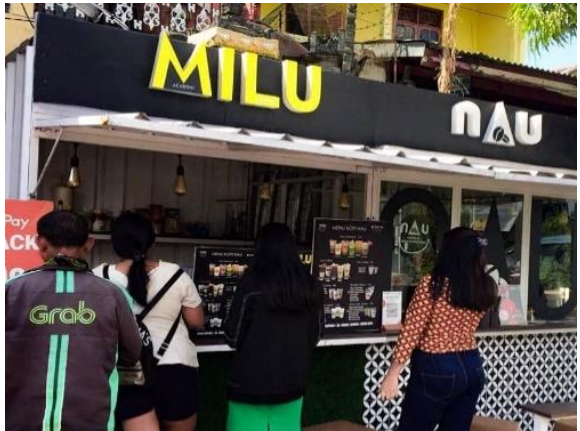

Figure 1. A Coffee Shop Available with A Variety Of Services

Source : Personal Documentation, 2020

The coffee shop in Figure 1 is a representation of the ability of someone who has a business spirit, understands the market, and is sensitive to opportunities that are present, even during the COVID-19 pandemic. Reference [14], consumptive behavior towards a product from the cultural industry is shown in the culture of the consumption community, where the product consumed turns into a sign object. Coffee is not just a drink, but more than that it functions as a person's marker. As [11], there is a process of creating meaning through a sign system, while the practice of meaning is an activity of creating meaning. For example, drinking coffee at shop $\mathrm{X}$, gives the meaning of someone as a person with a certain socioeconomic class. In practice, coffee business people, coffee shop owners, as Ritzer's idea in [19], cultural products are produced, introduced, offered, traded in various ways for the purpose of obtaining economic benefits, namely seeking profit.

During the COVID-19 pandemic, which for some people continue to live their lifestyle as a way to maintain their existence in society, coffee entrepreneurs have the opportunity to develop a business in the form of a coffee shop. In practice, today's coffee shops can be found in various regions with their variety and taste. Likewise, the services provided are not only drinking on the spot, but also serving sales by COD (cash on delivery) service. For those who drink at the coffee shop, wifi facilities are provided to attract customers who are currently actively using cellphones

\subsection{Packaged Sambal for Spicy Lovers}

The negative impact of large-scale social restrictions is also felt by farmers who experience problems with the distribution of their agricultural products. Reported in the West Java Province economic report in May 2020, the COVID-19 pandemic had an impact on the occurrence of product distribution constraints from one area to another, so that it could not reach the hands of consumers. This has an impact on the decline in prices of agricultural products, as a result of the accumulation of goods in production centers. The same condition also occurred in Bali, in Semarapura Regency which experienced a decrease in chili prices because they could not send goods 
and customers did not dare to take chilies to the area, which was due to a high increase in cases (Bagiarta, 11 June 2020). In fact, chili farmers choose to uproot their chili plants because the prices are very cheap and cannot cover operational costs.

Unstable the price of chili that occurs in some areas, not only makes farmers choose to remove and replace their chili plants with other plants that have the opportunity to provide better profits, but some farmers choose to process them into packaged chilies. Reference Mardhiyyah and Ningsih (2021), chili sauce is a sauce with the main ingredient in the form of chili which is processed in such a way, added with other ingredients, so as to produce various types of chili sauce. Indonesia, including Bali, which is rich in spices, provides a good business opportunity for the chili business, because it is able to produce various types of chili sauce according to the type of spice added in one package of chili product. Likewise, during the pandemic, some people who understand the technique of making chili sauce, are actually able to take business opportunities during the pandemic, as can be seen in Figure 2.

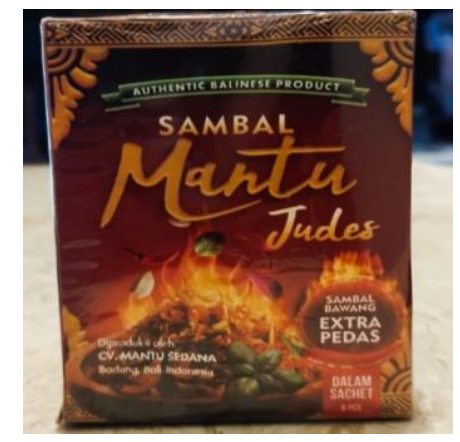

Figure 2. One of the Packaged Chili Products in the Pandemic Period

Source : Arsa, 2020

Local food or traditional food [20], its development is a cultural product that can provide economic benefits, including during the COVID-19 pandemic. In practice, local raw materials are processed into traditional foods, not for personal consumption, but for sale [19] in the hope of making a profit, through the touch of hands with creative and innovative ideas. In this case, community culture, local raw materials, traditional concepts that are touched with modern work methods, are able to package local culinary into products with high selling value.

The chili business that is rife in social media is a representation of human nature as a thinking creature (animale rationale), a working creature (homo faber, homo laborans), [7], so that humans always think creatively and work hard in order to fulfill their needs. necessities of life. Choosing social media as a potential market place to sell their chili products, is due to the convenience it provides, which is not requiring a shop, which does not mean that the income received is able to cover the rental of the shop. In this case, product advertisements using social media, such as Facebook, Instagram, and WhatsApp, can touch consumers who are potential targets. Through interesting and unique content and documentation, chili businessmen try to construct the reality of society and represent their chili products, so that consumers become interested in buying them. [21], media culture, advertising on social media, are produced for consumers by type (genre), by following established formulas, codes and rules, with the aim of providing benefits for product sellers.

\subsection{Hand Sanitizer in Various Packaging}

The global, global and global COVID-19 pandemic has forced health teams at the international, national and local levels to make a mandatory policy to use hand sanitizer if they cannot wash their hands with soap and running water. As emphasized by the World Health Organization and Unicef in the Interim Guidance issued on July 29, 2020, explaining the importance of providing alcohol-based antiseptic (hand sanitizer) with the aim of maintaining hand hygiene. These antiseptics are known as hand sanitizers. Hand sanitizer [22], is a product made by utilizing alcohol as the basic ingredient of the product, which is made in the form of a spray or gel that can be used to clean hands, especially when outside the home and there is no place to wash hands. washing hands.

The high demand for hand sanitizers, [23] explained that this condition had become a business opportunity in the midst of the COVID-19 pandemic, so that business people who took the opportunity were able to make a profit. Hand sanitizer [24], which is informed that it is very effective in killing transient and resident flora, can even kill germs in less than 30 seconds, in practice it is the choice of many people, especially those who work in offices or are often outside the home. with a specific purpose. In fact, [25] explained that excessive public attitudes occurred widely when the spread of the COVID19 virus was reported in various media, which gave birth to a type of consumer, namely panic buying. The panic occurred not only because people were afraid of a frightening disease, but also the availability of hand sanitizer products, which had experienced an increase in prices due to the scarcity of product availability at the beginning of the pandemic.

The panic buying phenomenon that occurs in the community, it becomes an opportunity for business people, especially those engaged in the health business to increase and develop health production in the form of hand sanitizers. In practice, the production of hand sanitizers requires a touch of technology that can support the process of developing creative and innovative products [10], both in the production, distribution and marketing processes. In this case, the general understanding of the community is that health products are produced using certain technologies, so that people who want to take business opportunities as sellers of health products in the form of hand sanitizers, are more likely to become resellers. In its implementation, until 
now hand sanitizers are not only sold by pharmacies which are official institutions as places to sell health products, but also sold by modern and traditional shops, even on the side of the road, as can be seen in the figure 3.

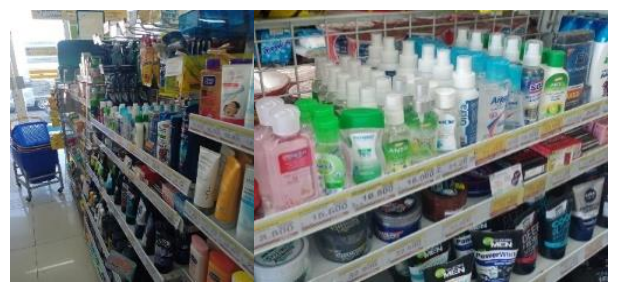

Figure 3. Hand Sanitizer Products In One of The Modern Markets.

Traditional markets also take advantage of the high demand for hand sanitizers, given the massive layoffs of employees, requiring people to be able to take advantage of opportunities that arise as soon as possible, as can be seen in the Figure 4.

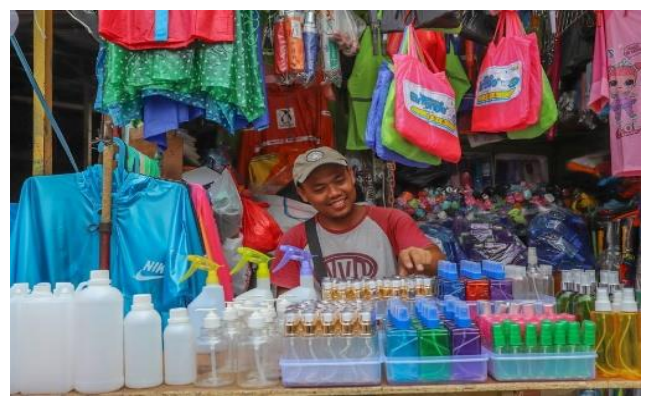

Figure 4. Market Traders Selling Hand Sanitizer Liquids and Bottles.

In the development of instant hand sanitizer products, hand sanitizers have become creative and innovative products, which are manifested in the form of product designs that adapt to market needs, so that these products are able to grow desire (desirability) and marketability (sales ability). This is in line with the idea of [19] that the demand for industrial capitalism is very dependent on the continuous consumption of goods, so that new designs of a product must continue to be carried out, therefore the meaning of design has shifted in line with the evolution of consumer culture as a whole. Thus, [6]'s idea that every individual must be well informed and always able to adapt to changes that occur appropriately, becomes a role model for industry players who must continue to analyze trends that develop in society.

\subsection{Patterned Masks for the "New Normal" Lifestyle}

A product that is very widely circulated in the market, and can be found very easily during the COVID-19 pandemic, is a mask. Masks, [25] explained that almost all Indonesian people were looking for after the announcement of 2 Indonesian citizens who were positive for the Covid-19 virus on March 2, 2020. At that time, many business people were cheating by buying lots of masks, doing stock, so masks become scarce in the market, and the price becomes very high. In this condition, [25] mentions two types of consumers who were born simultaneously, namely panic buying (people buying products for fear of not getting any) and buying frenzies (people who are worried because the price of masks is beyond common sense, so they buy in large quantities). a lot even at a very high price).

Along with the increasing number of cases, the number of masks being scarce, the government certainly does not remain silent, but immediately looks for ways to regulate the market, so that products can still be sold, but the public can still afford them, considering that masks during the pandemic are mandatory to be used inside. human daily life. When masks are scarce, and people panic, there are some business people who rely on their high creativity and ability to innovate products, produce cloth masks of various sizes, materials and designs. Long before the covid-19 pandemic, [26] had designed masks as personal protective equipment for female motorcyclists. In his research, masks were designed by applying certain colors, so that they could be a reference for motorcycle users to still look stylish, but protected from air pollution.

The high demand for masks has not only made health mask producers in the form of large factories increase their production volumes with the aim of increasing sales in order to achieve maximum profit during the pandemic, but also some local people produce with various approaches. Reference [27] wrote about making cloth masks in Sukaratu Village, for example, in addition to the aim of producing protective equipment independently, it also aims to generate income for the local community. In its development, there are now many local craftsmen who make cloth masks, with certain materials, which are also accompanied by unique motifs, such as batik, or motifs typical of a region, as can be seen in the Figure 5.

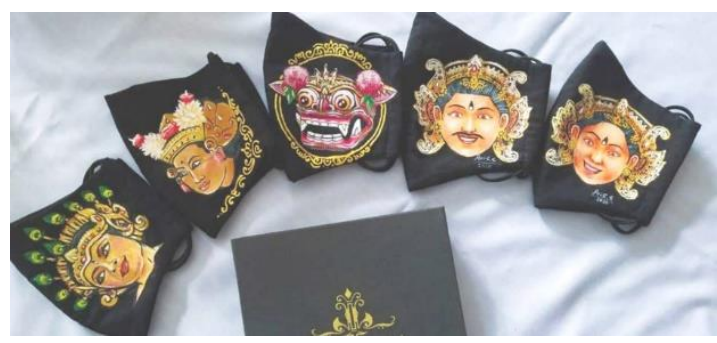

Figure 5. Patterned Masks for the "New Normal" Lifestyle

In its development, where masks have shifted into fashion, namely a lifestyle choice in the "new normal" era. New normal as a new lifestyle [28] which is regulated in the Decree of the Minister of Health Number HK.01.07/MENKES/328/2020, has provided positive benefits for business actors engaged in fashion. Masks in practice are then used as a way to introduce one's identity 
and lifestyle. In this case, humans as homo consumers, homor aesthethicus, and homo valens [7], become an opportunity during the covid-19 pandemic. Humans will buy anything that has aesthetic value, and is able to support their lifestyle, as an up-to-date form of selfrepresentation, is a societal phenomenon that becomes an opportunity for capitalists, who are business-minded.

\section{CONCLUSION}

This paper aims to show the existence of business opportunities during the COVID-19 pandemic. In this case, economic life is not completely paralyzed as a result of the spread of the virus which ultimately has a negative impact on some aspects of the economy. In practice, many parties are actually able to take advantage of business opportunities from the COVID-19 pandemic. Based on observations made through articles and information on business opportunities during the pandemic on the internet and in the field, there are several creative and innovative products that are able to survive and thrive. Nowadays, there are many coffee shops that we can easily find, available with various brands, and offer a variety of flavours. Packaged sambals with various flavours are also offered through various social media as a solution for those who like spicy food. Hand sanitizers with various types and packaging forms are also sold, not only in pharmacies and modern stores, but also in traditional markets. Likewise, masks as personal protection are also produced by adding unique motifs, to help consumers remain able to maintain their lifestyle during the pandemic.

\section{REFERENCES}

[1] I. B. Wirawan, Teori-teori Sosial dalam Tiga Paradigma (Fakta Sosial, Definisi Sosial, dan Perilaku Sosial). Jakarta: Prenada Media Grup, 2012.

[2] S. Listyorini, "Analisis Faktor-faktor Gaya Hidup dan Pengaruhnya terhadap Pembelian Rumah Sehat Sederhana (Studi pada Pelanggan Perumahan Puri Dinar Mas PT. Ajisaka di Semarang)," J. Adm. Bisnis, vol. 1, no. 1, pp. 12-24, 2012.

[3] S. S. Hadiwijoyo, Perencanaan Pariwisata Perdesaan Berbasis Masyarakat (Sebuah Pendekatan Konsep). Yogyakarta: Graha Ilmu, 2012.

[4] F. N. Ulya, "Akibat Covid-19, Kerugian Ekonomi Tahun 2020 Capai Rp 1.356 Triliun,” Kompas.com, 2021.

[5] C. Wibisono, "Pengaruh Motivasi Mu'amalat (Bekerja dan Berproduksi, Kebutuhan Sekunder, Kebutuhan primer) terhadap Prestasi Kerja yang
Religius," Ijtihad J. Wacana Huk. Islam dan Kemanus., vol. 13, no. 2, pp. 233-252, 2013.

[6] H. Soedjatmiko, Saya Berbelanja, Maka Saya Ada: Ketika Konsumsi dan Desain Menjadi Gaya Hidup Konsumerisme. Yogyakarta: Jalasutra, 2008.

[7] F. M. Borgias, Manusia Pengembara: Refleksi Filosofis tentang Manusia. Yogyakarta: Jalasutra, 2013.

[8] W. Saputra, Industri Kreatif. Jakarta: Baduose Media, 2010.

[9] M. E. Pangestu, Rencana Pengembangan 14 Sub Sektor Industri Kreatif 2009-2015 (Buku 1), Buku 1. Jakarta: Kelompok Kerja Indonesia Design Power: Departemen Perdagangan Republik Indonesia, 2008.

[10] M. . Mohd-Azmi, F. F. A. Jesse, S. A. Sarah, S. Roslan, A. Zuraidah, and I. U. Hambali, "Transforming Agriculture Research into Commercialisation: Experience of Universiti Putra Malaysia," Pertanika J. Soc. Sci. Humanit., vol. 24, no. 3, pp. 907-921, 2016.

[11] C. Barker, Cultural Studies: Teori dan Praktek. Yogyakarta: Bentang, 2005

[12] C. Barker, Kamus Kajian Budaya. Yogyakarta: Kanisius, 2014.

[13] D. Ihde and L. Malafouris, "Homo Faber Revisited: Postphenomenology and Material Engagement Theory," Philos. Technol., vol. 32, no. 1682, pp. 120, 2019.

[14] D. T. K. Solikatun and D. Argyo, "Perilaku Konsumsi Kopi sebagai Budaya Masyarakat Konsumsi: Studi Fenomenologi Pada Peminum Kopi di Kedai Kopi Kota Semarang,” J. Anal. Sosiol. UNS, vol. 4, no. 1, pp. 60-74, 2015.

[15] M. Wolfson, "Classical Philosophies of the Self in Neoclassical Economics," Hist. Polit. Econ., vol. 26, no. 2, pp. 297-325, 1994.

[16] D. Chaney, Life Style: Sebuah Pengantar Komprehensif. Yogyakarta: Jalasutra, 2004.

[17] A. Adlin, "Resistensi Agama: Gerakan Keagamaan sebagai Resistensi Gaya Hidup," Resist. Gaya Hidup Teor. dan Realitas, pp. 91-162, 2006.

[18] Y. A. Pilliang, "Imagologi dan Gaya Hidup: Membingkai Tanda dan Dunia," Resist. Gaya Hidup Teor. dan Realitas, pp. 71-90, 2006.

[19] B. Suyanto, Sosiologi Ekonomi, Kapitalisme dan Konsumsi di Era Masyarakat Post Modernisme. Jakarta: Kencana Prenada Media, 2014. 
[20] N. D. Widiastini, N. M. A., Arini, R. P., \& Andiani, "Pengemasan Makanan Lokal sebagai Produk Wisata Kuliner di Bali," J. Ilm. Pariwisata, vol. 19, no. 2, pp. 121-133, 2014.

[21] D. Kellner, Budaya Media Cultural Studies, Indentitas dan Politik: Antara Modern dan Posmodern. Yogyakarta: Jalasutra, 2010.

[22] R. Nakoe, N. A. S Lalu, and Y. A. Mohamad, "Perbedaan Efektivitas Hand-Sanitizer Dengan Cuci Tangan Menggunakan Sabun Sebagai Bentuk Pencegahan Covid-19," Jambura J. Heal. Sci. Res., vol. 2, no. 2, pp. 65-70, 2020, doi: 10.35971/jjhsr.v2i2.6563.

[23] S. N. Rohmah, "Adakah peluang bisnis di tengah kelesuan perekonomian akibat pandemi Corona virus Covid-19?," 'ADALAH ; Bul. Huk. Keadilan, vol. 4, no. 1, pp. 63-74, 2020.

[24] Ministry of Health Republic of Indonesia, Pusat Promosi Kesehatan dalam Pencapaian PHBS. Jakarta: Ministry of Health Republic of Indonesia, 2008.

[25] M. A. Shadiqi, R. Hariati, K. F. A. Hasan, N. I'anah, and ..., "Panic buying pada pandemi COVID-19: Telaah literatur dari perspektif psikologi," J. Psikol. ..., vol. 19, no. 02, pp. 131-141, 2020, doi: 10.7454/jps.2021.15.

[26] A. Muthia and A. Hendrawan, "Perancangan Masker Sebagai Alat Pelindung Diri Bagi Pengendara Sepeda Motor Wanita," J. ATRAT, vol. 5, no. 3, pp. 208-219, 2017.

[27] D. Sunaryo, "Pembuatan Masker Kain Sebagai Pencegahan Penularan Virus serta Mengoptimalkan Pendapatan di Masa Pandemi COVID-19 bagi Masyarakat di Desa Sukaratu," J. Abdidas, vol. 1, no. 4, pp. 183-192, 2020, [Online]. Available: doi: 10.31004/abdidas.v1i4.40.

[28] A. Rosidi and E. Nurcahyo, "Penerapan New Normal (Kenormalan Baru) Dalam Penanganan Covid-19 sebagai Pandemi Dalam Hukum Positif," J. Ilm. Rinjani, vol. 8, no. 2, pp. 193-197, 2020. 